\title{
Fashion Anglicisms in Modern Greek: A preliminary investigation
}

\author{
George J. Xydopoulos ${ }^{1}$ \\ University of Patras
}

Rania Papadopoulou ${ }^{2}$
University of Patras \& University of Lyon

\begin{abstract}
English nowadays is the dominant language in the domain of fashion since English and American companies lead the fashion industry worldwide. As a result, a high number of English fashion loanwords have entered the languages of the world and become part of their vocabulary. A considerable number of Anglicisms regarding fashion is attested in Modern Greek too. This work is a preliminary investigation of fashion Anglicisms in MG through their appearance in Greek online shops and social media pages of fashion stores and magazines. Our investigation shows that fashion Anglicisms in MG are present in the MG vocabulary and are used by MG speakers in their transliterated or non-transliterated forms. In particular, we examine in detail how Anglicisms exist in their non-transliterated form in the MG language system, a fact that is, among others, related to prestige perceptions of English that are dominant in Greek society.
\end{abstract}

Keywords: Anglicism, borrowing, loanword, fashion

1 Corresponding author: Department of Philology- University of Patras, University Campus, Rio Patras, 26504, Greece.

Email: gixydo@upatras.gr

$2 \quad$ Email: ranpap@upatras.gr 


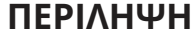

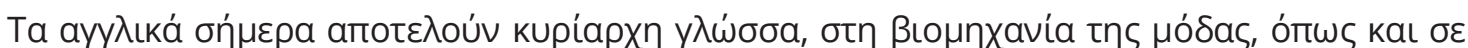

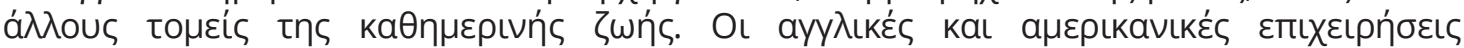

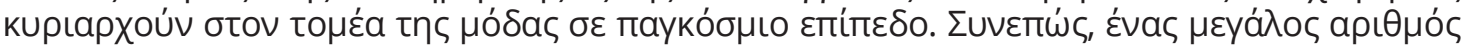

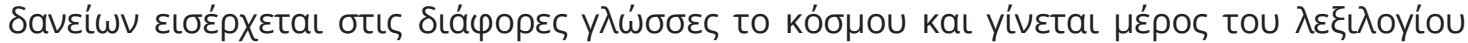

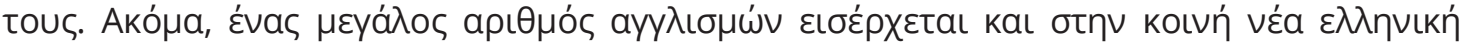

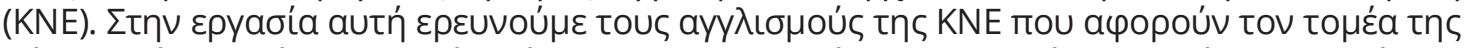

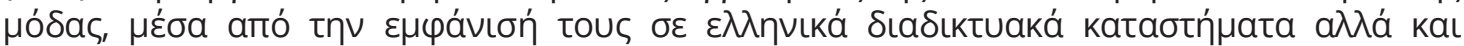

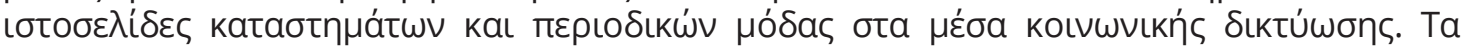

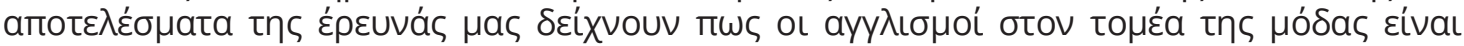

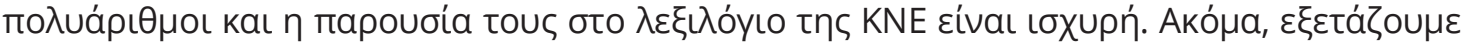

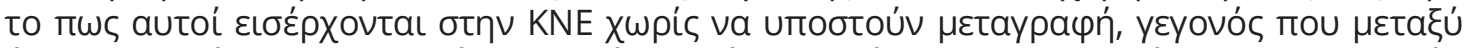

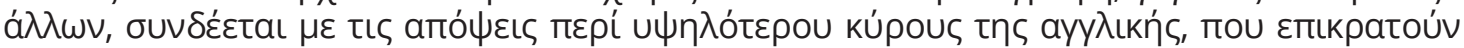

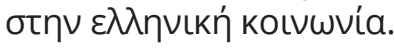

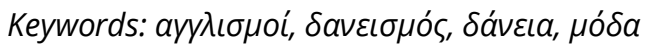

\section{Introduction}

In this work, we investigate fashion Anglicisms in Modern Greek (MG). Nowadays, MG is widely influenced by English and consequently Anglicisms are found in many aspects of everyday language, such as sports, technology, the Internet and the social media, as well as fashion, as discussed in this paper. The term Anglicism refers to an English element being part of the vocabulary of another language. The term includes cases of borrowings that come from English (Fischer, 2008, p. 8). Pulcini, Furiassi \& Rodríguez González (2012, pp. 5-6) state that Anglicisms can be found in all kinds of linguistic levels and they include not only loanwords, but also other kinds of borrowing such as adapted loans, calques or hybrids.

In section 2, we discuss the influence of English worldwide, with our focus being its influence on the fashion vocabulary of MG. In section 3, we briefly refer to the phenomenon of borrowing, focusing on the reasons why languages borrow elements from one another. In section 4, we present our methodology and, in section 5, we analyse our data. Particularly, in 5.1 we present and offer a typology of the Anglicisms collected, taking into consideration the semantic fields they belong to. In 5.2, we examine Anglicisms under investigation from a lexicological perspective. Moreover, we study the presence of Anglicisms in Greek popular online fashion stores (section 5.3), as well as in the social media pages of fashion stores and magazines (section 5.4). In section 6, we make some remarks based on our findings regarding the use of fashion Anglicisms in Greek society. 


\section{English in the Domain of Fashion}

English nowadays is considered as the global language of communication, since it is used by a large number of speakers around the world. Consequently, English is regarded as the dominant language in many domains of everyday life (Crystal, 2003, pp. 3-4). The presence of English is pervasive worldwide in domains such as politics, business, the Internet and the mass media, fashion, the movie and music industries (Crystal, 2003, pp. 86-104; Pulcini, Furiassi \& Rodríguez González, 2012, pp. 2-4). The role of the Internet and the mass media is particularly significant for the spread not only of English words, but also of the English and American culture and lifestyle (Hjarvard, 2004, p. 75).

Considering MG, over the past decades, from the 60s until late 90s, the main source of fashion borrowings was French, since it was regarded as a language of prestige (Anastasiadi-Simeonidi, 1994, pp. 115-117). Examples of French loanwords in the field of fashion can be seen in (1):

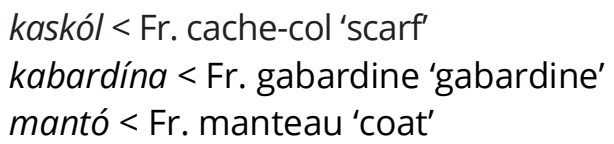

Anastasiadi-Simeonidi (1994, pp. 133-137) in her work about MG borrowing, reports that French was the main donor language in the domain of fashion in the period from the 60s until late 90s. However, she also gives examples of English fashion loanwords for the same period, although they were considerably fewer than the French loanwords in the domain of fashion. Examples of English fashion borrowings are given in (2). It is worth noticing that at that time English fashion loanwords mostly concerned men's or unisex clothing.

$$
\begin{aligned}
& \text { pulóver }<\text { Engl. pullover } \\
& \text { tísert }<\text { Engl. T-shirt } \\
& \text { tzáket }<\text { Engl. jacket }
\end{aligned}
$$

Nowadays, it seems that English dominates the fashion vocabulary of MG, since the presence of Anglicisms is evident in all fashion-related sources, as we shall see in the following sections. The Internet and the social media contribute to the spread of English at a world-wide level (Hjarvard, 2004, p. 86) and consequently the latest fashion trends are introduced rapidly through them. Bloggers or 'fashionistas' 3 of international fame and influence are widely followed by Greeks, who not only adopt

https://www.urbandictionary.com/define.php?term=fashionista 
the latest fashion trends but also incorporate English fashion terms in their vocabulary. As a result, their vocabulary is widely influenced by English loanwords or loan translations. In the following section, we will give a brief overview of the phenomenon of borrowing before we move on to the analysis of our data.

\section{Borrowing}

Languages tend to borrow elements from another linguistic system due to necessity or social factors. Regarding socially-driven factors, McMahon (1994, p. 202) states that this phenomenon is related to perceptions of prestige, since speakers of a linguistic community tend to borrow elements from another language that is considered more prestigious and influential at a particular time. Words do not necessarily need to be borrowed, since a term to name a specific object or concept may already exist in the recipient language. Speakers borrow elements that most of the time coexist with native elements, being motivated by the status of the donor language and not by real necessity (Bybee, 2015, pp. 191-192).

Balteiro \& Campos (2012, pp. 239-240), while stating the reasons why languages borrow and use Anglicisms, mention the fact that the English language and culture lead the way and set trends in many aspects of everyday life and, undoubtedly, in the world of fashion. As a consequence, the recipient language does not have sufficient time to adapt existing lexical elements or create new ones. For example, the Anglicism bralet found in MG, refers to particular type of clothing that did not exist before. The reason of language economy may also contribute to the use of Anglicisms since, for example, the use of the shorter form jeans is preferable to the MG tzin pantelóni 'jeans trousers'. Finally, globalization seems to favour the use of Anglicisms in order to facilitate communication among specialists in the field and people following the latest fashion trends.

\section{Methodology}

In order to investigate fashion Anglicisms in MG, we compiled a small corpus of 109 items. We collected our data mainly through the Internet, searching web pages of online shops, online fashion magazines, Facebook and Instagram accounts of stores and fashion magazines (cf. Balteiro \& Campos 2012, p. 241). More specifically we gathered our data from the sources shown in Table 1: 
Polish Anglicisms in the fields of leisure, fashion

and entertainment against historical background

\begin{tabular}{lll}
\hline Online shops & $\begin{array}{l}\text { Facebook pages of } \\
\text { stores and magazines }\end{array}$ & $\begin{array}{l}\text { Instagram pages of stores and } \\
\text { magazines }\end{array}$ \\
\hline Bershka $^{4}$ & Pink Woman Official & Pink Woman Official \\
\hline Dangerous Minds $^{7}$ & Marie Claire Greece & Marie Claire Greece \\
\hline Pull and Bear & & \\
\hline Zara $^{10}$ & & \\
\hline
\end{tabular}

Table 1. Online sources of data collection.

We chose these particular online shops, stores and magazines as we consider them as the best-known to Greek society and especially to Greek customers. These online shops are daily visited and are the first choice of customers that wish to shop online. These online shops are known to customers since they are electronic outlets of physical shops in many Greek cities, e.g. Zara and Bershka. ${ }^{12}$ Fashion pages in the social media accumulate a considerable number of like-clicks and followers. ${ }^{13}$

We checked the meaning ${ }^{14}$ of the words in our sample (see Appendix) and tried to find the equivalent term in MG. We examined our data regarding the type of product

4 International company of Spanish origin, part of the Spanish Inditex group, https://www.bershka.com/gr/yuvaıka-c1010193132.html

5 Cloth Company of Greek origin, https://www.facebook.com/PINK.WOMAN.OFFICIAL/

6 https://www.instagram.com/pinkwomanofficial/

7 Greek shop based in Alexandroupoli, Thrace. Its online shop is widely known all over Greece. http://dangerousminds.gr/greek/

8 Women's magazine of French origin, issued in Greece. https://www.facebook.com/PINK.WOMAN.OFFICIAL/

$9 \quad$ https://www.instagram.com/marieclairegreece/

10 International company of Spanish origin, part of the Spanish Inditex group, https://www.pullandbear.com/gr/vuvaıkía-c1010141503.html

11 International company of Spanish origin, part of the Spanish Inditex group, https://www.zara.com/gr/

12 For example, Zara operates 42 stores in Greece.

13 Pink Woman Official has 281,485 like-clicks on Facebook and 139,000 Instagram followers and Marie Claire Greece has 170,427 like-clicks on Facebook and 28,700 Instagram followers.

14 We looked up for the English definition in http://dictionary.cambridge.org, https://en.oxforddictionaries.com, http://www.urbandictionary.com, http://www.dictionary.com, https://www.wikipedia.org. 
they denote, that is, whether they are clothing items, footwear, accessories, etc. and tried to determine whether the Anglicism is the only term used to describe an item or if it co-occurs with an equivalent MG term (see section 5.1). Furthermore, we examined the type of borrowing of our sample Anglicisms and recognized the grammatical classes they belong to (see section 5.2). Moreover, we checked the websites of some online shops in Greece, so as to investigate whether the Anglicisms are used in transliterated or non-transliterated forms (see section 5.3). We followed the same procedure in order to examine the use of the Anglicisms in the social media pages of stores and magazines under consideration (see section 5.4).

This work is to be considered a preliminary investigation of fashion Anglicisms in MG. The existent MG corpora, the Hellenic National Corpus (HNC) ${ }^{15}$ and the Corpus of Greek Texts (CGT), ${ }^{16}$ do not include a wide range of texts and text genres, therefore it is not possible to obtain representative statistical information and data frequencies. In fact, we were able to retrieve only a few Anglicisms from our sample, which are longstanding loanwords in MG, among which tzin 'jeans' and sorts 'shorts', which are well established in the lexical stock of the Greek language. The Anglicism tzin 'jeans' shows a frequency of $0.0063 \%$ in the HNC and $0.0019 \%$ in the CGT. Similarly, the Anglicism sorts 'shorts' has a frequency of $0.0005 \%$ in the HNC and $0.0004 \%$ in the CGT. Currently, we are working on the compilation of web-based corpora for MG which will include a wide range of texts genres so that it will be possible to obtain representative statistical information on the issue under investigation.

\section{Data Analysis}

In this section, we present the collected fashion Anglicisms in MG. As already mentioned, we will illustrate and analyse our data following two different procedures. In section 5.1 we will present our data based on the semantic field they belong to, while in section 5.2 we will attempt a lexicological approach regarding Anglicisms under consideration. In section 5.3 we will check the presence of fashion Anglicisms in Greek online shops as well as on social media accounts of stores and fashion magazines (section 5.4).

15 http://hnc.ilsp.gr

16 http://www.sek.edu.gr 


\subsection{Semantic fields of fashion Anglicisms in MG}

Fashion Anglicisms in MG are found in a wide range of fashion fields. More specifically they are used to refer to clothes, footwear, lingerie, accessories, fabrics or materials, and to people that are either working in the fashion industry or have fashion as a hobby, to styles and to other fashion related topics.

- Clothes

(6) blazer [bléizer]: a type of jacket, in MG sakáki, 'jacket'

(7) jacket [tzácet]: a short coat, in MG sakáki 'jacket' or paltó 'coat'

(8) jeans [dzin]: trousers made of denim

(9) jeggings [dzéjinz]: tight-fitting stretch trousers for women, styled to resemble a pair of denim jeans

(10) jersey [zérsei]: a piece of wool or cotton clothing that is worn on the upper part of the body and has sleeves but no opening at the front, in MG pulóver 'pull-over'

(11) jumpsuit [dzámpsut]: a piece of clothing that covers both the upper body and the legs, in MG olósomi fórma 'jumpsuit'

(12) leggings [léfinz]: very tight trousers made from a material that stretches easily, in MG kolán 'leggings'

(13) shorts [sórts]: trousers that end above the knee or reach the knee

(14) strapless [stráples]: a piece of clothing that does not have pieces of material going over the shoulders

(15) sweater [suéter]: a piece of clothing, typically with long sleeves and made from wool, that is worn on the upper part of the body, in MG fúter 'sweater'

(16) top [top]: any piece of light clothing worn on the part of the body above the waist, in MG blúza 'top'

t-shirt [tísert]: a simple piece of clothing, usually with short sleeves and no collar, that covers the top part of the body, in MG kodomániko 't-shirt'

As we can see, many of the Anglicisms related to clothes co-exist with the native MG terms, e.g. top co-exists with the MG term blúza 'top', or the English term jumpsuit coexists with the native term olósomi fórma 'jumpsuit'. In some cases, the newly imported English term co-exists with the MG term which is also a loanword either from English or French, but it is fully adapted and is now part of MG vocabulary. Also, as we see in examples (6) and (7) new terms have been imported in order to describe a piece of clothing that is similar to a jacket or coat to replace the MG term sakáki 'jacket'. Finally, for the terms in (9), (13) and (14) there is no equivalent term in MG that can replace them and consequently they seem to have entered the MG vocabulary along with the new item. 
Regarding Anglicisms that are related with footwear, only the term sneakers seem to co-exist with the MG term athlitiká (papoútsia) 'sports shoes', whereas in all other cases there is no MG term to describe the new item.

- Footwear

(18) ankle boot [ánkl but]: short boot that covers only the foot and ankle

(19) mules [mnúls]: type of shoes

(20) peep-toe [píptou]: used to describe shoes that show part of the big toe

(21) sneakers [sníkers]: a type of light, comfortable shoe suitable for sports, in MG athlitiká (papoútsia) 'sports shoes'

All terms related to lingerie have been imported into MG vocabulary along with the item they represent since there is no MG word that can be used in order to describe them.

- Lingerie

baby doll [béibi dol]: type of sexy lingerie, a style of women's clothing especially short, high-waisted, short-sleeved dresses

bralette [bralét]: an unlined bra without underwire or clasp push-up [púsap]: a piece of underwear for women that pushes the breasts up together so that they look bigger or more noticeable

Terms related to fashion accessories seem to co-exist with the MG terms. In the cases of (25) and (27) the MG term is a loan translation of the equivalent term of English.

\section{- Accessories}

backpack [bákpak]: a large bag used to carry things on your back, in MG sakídio plátis 'backpack' clutch (bag) [klats bag]: a small flat bag without a handle, in MG fákelos 'envelope' or tsadáki 'small bag'

handbag [cándbag]: a small bag for money, keys, make-up etc., in MG tsáda or tsáda xeirós 'handbag'

All terms related to fabric or material seem to have been entered MG vocabulary along with the new material and as a result the English term is used to describe them. An exception is the English term denim that seems to co-exist with the MG term tzin 'jeans', an English loanword from the past that is now is part of the MG vocabulary.

- Fabrics or materials 
(28) denim [dénim]: a thick, strong, cotton cloth, often blue in color, used especially for making jeans, in MG tzin 'jeans'

(29) nylon [náilon]: an artificial substance used especially o make clothes, etc.

(30) organza [oryádza]: a type of thin, stiff, transparent cloth, made of silk or artificial thread

(31) suede [suéd]: leather that is slightly rough to touch and is not shiny

(32) tulle [túli]: a light cloth used on dresses, to decorate hats, or for particular types of veil

(33) viscose [viskóz/viskózi]: a smooth material similar to silk but made from cellulose

English terms related to people that work for the fashion industry or have fashion as a hobby seem to have entered the MG vocabulary along with the idea/concept they represent, since there is no MG term that can replace them.

- People related to fashion

fashion icon [fásjion áikon]: someone that you look up to or inspires your fashion style fashionista [fasjionísta]: a term used to define a woman with a penchant for shopping and a natural flair for combining both current and vintage fashionable trends

Almost all examples presented below concerning different aspects of style seem to co-exist with equivalent MG terms. Exceptions are examples (38) and (41), where the new term does not exist in MG vocabulary.

- Styles

(40) trendy [tréndi]: modern and influenced by the most recent fashions or ideas, in MG modérno 'modern'

(41) vintage [víntadz]: of high quality and lasting value, or showing the best and most typical characteristics of a particular type of thing

Similarly, as in the previous case, almost all examples of Anglicisms related to fashion seem to co-appear with the MG equivalent terms, apart from the terms in 
(48) and (49) where the English term seems to have entered the MG vocabulary along with the idea/concept it represents.

- Other Anglicisms related to fashion

(42) brand [brand]: a type of product made by a particular company, in MG márka or fírma 'brand'

(43) catwalk [kátyuok]: the long, narrow stage that models walk along in a fashion show, in MG pasaréla 'catwalk'

(44) design [dizáin]: a pattern used to decorate something, in MG sxédio 'design'

(45) look [luk]: a set of clothes that match together, a particular style in clothes, in MG emfánisi 'look'

(46) outfit [áutfit]: a set of clothes for a particular occasion or activity, in MG sínolo 'outfit'

(47) trend (fashion trend) [trénd]: a new development in clothing, make-up etc., in MG tási 'trend'

(48) dress code [dres kóud]: a set of rules of what you can wear

(49) must-have [mástxav]: a must-have object is something that many people want to own

\subsection{A lexicological approach to fashion Anglicisms in MG}

In this section, we will attempt a lexicological approach to Anglicisms related to the domain of fashion in MG. Fashion Anglicisms in MG can be either loanwords (section 5.2.1), loan translations (5.2.2) or hybrid patterns (section 5.2.3):

\subsubsection{Loanwords}

Almost all Anglicisms presented in the section 5.1. above, are cases of direct borrowings, and in particular, cases of non-adapted loanwords, since the borrowing element enters the recipient language maintaining the form and the meaning that it had in the donor language. Most of the cases that we saw in the previous section are cases of prestige borrowings, since the loanword co-exists with the MG term. However, there are also cases of necessity borrowings, since there is no MG term to define the newly imported element and consequently the term comes along with the new element (McMahon, 1991, pp. 201-202). English fashion loanwords in MG can belong to different lexical or grammatical categories: nouns (50), adjectives (51), compounds (52), collocations (53) and (54) or phrases (55):

(50) Nouns 
- blazer [bléizer]: a type of jacket, in MG sakáki, 'jacket'

- brand [brand]: a type of product made by a particular company, in MG márka or fírma 'brand'

- fashionista [fasjionísta]: a term used to define a woman with a penchant for shopping and a natural flair for combining both current and vintage fashionable trends

- outfit [áutfit]: a set of clothes for a particular occasion or activity, in MG sínolo 'outfit'

- trend (fashion trend) [trénd]: a new development in clothing, make-up etc., in MG tási 'trend'

- t-shirt [tísert]: a simple piece of clothing, usually with short sleeves and no collar, that covers the top part of the body, in MG kodomániko 't-shirt'

(51) Adjectives

- casual [kázual]: not formal or not suitable for special occasions, in MG kathimerinós 'everyday'

- handmade [xándmeid]: made using the hands rather than a machine, in MG xeiropoiitos 'handmade'

- must-have [mástxav]: a must-have object is something that many people want to own

- oversized [óversáizd]: bigger than the usual size

- trendy [tréndi]: modern and influenced by the most recent fashions or ideas, in MG modérnos 'modern'

(52) Compound nouns

- ankle boot [ánkl but]: short boot that covers only the foot and ankle

- cocktail dress [koktéil dres]: a dress worn for a special occasion in the evening, such as party or dance

- crop top [krop top]: a piece of clothing for a woman's top half that does not cover her stomach

- fashion icon [fásjion áikon]: someone that you look up to or inspires your fashion style

- handbag [xándbag]: a small bag for money, keys, make-up etc., in MG tsáda or tsáda xeirós 'handbag'

Fashion Anglicisms in MG usually originate from collocations that are related to specific ways of dressing. The most frequent words that form collocations are the 
nouns look and style, as in the examples below:

(53) Collocations with look

- beach look [bits luk]: a look appropriate for the beach, in MG emfánisi paralías 'beach look'

- casual look [kàzual luk]: an everyday, non-formal look, in MG kathimeriní emfánisi 'casual look'

- extreme look [ekstrím luk]: an exaggerated look, in MG ipervolikí emfánisi 'extreme look'

- office look [ófis luk]: a look appropriate for the office and work, in MG emfánisi grafíou 'office look'

- girly look [jérli luk]: a look that refers to teenage girls, in MG koritsístiki emfánisi 'girly look'

- 50s, 60s, 70s etc. look [fíftiz, síkstiz, séventiz, luk]: a look that refers to these decades, in MG emfánisi tis dekaetías tou '50, '60, '70, '50s, 60s, 70s look'

- spring summer etc. look [sprinł, sámer luk]: a look suitable for the spring, summer etc. emfánisi gia ániksi, kalokaíri 'spring, summer look'

(54) Collocations with style

- boho chic style [bóxo stil/stáil]: a style that is partly bohemian and partly chic, in MG kompsó xípiko stil 'hippie chic style'

- boyfriend style [bóifrend stil/stáil]: any style of women's clothing that was modi-fied from a corresponding men's garment

- casual style [kázual stil/stáil]: an everyday, non-formal style, in MG kathimerinó stil 'casual style'

- hippie style [çípi stil/stáil]: a style that refers to the hippie way of dressing, in MG xípiko stil 'hippie style'

- street style [strit stil/stáil]: any offbeat or avant-garde fashion inspired by contemporary culture of urban street people

- urban style [úrban stil/stáil]: a look that refers to the style of people that play or listen to hip-hop and R\&B music

Fixed phrases can be an element of borrowing, too. For example, the phrase in (55) below is usually found in magazines or fashion blogs that give advice to readers on how to get dressed, which clothes to choose, what to or not to avoid in order to be well-dressed, desired and admired by others.

(55) dress to impress [dres tu imprés]: how to get dressed in order to be 
admired

\subsubsection{Loan translations and hybrid structures}

Apart from genuine English loanwords in the fashion domain, MG also imports loan translations or coins hybrid structures. Anglicisms as loan translations in MG fashion vocabulary are shown in the examples below:

(56) gramí álfa 'A-line'

(57) metalikés leptoméries 'metallic details'

(58) psilómesos 'highwast(ed)'

(59) sakídio plátis 'backpack'

(60) tsáda xirós 'handbag'

Hybrid structures made of English loanwords and of elements of MG origin are as the ones given below:

(61) flat papútsia 'flat shoes' instead of ísia papútsia 'flat shoes'

(62) pencil fústa/fórema 'pencil skirt/dress' instead of stení fústa/ steno fórema 'pencil skirt/dress'

(63) teleftéo trend 'last trend' instead of teleftéa tási 'last trend'

(64) total black emfánisi 'total black look' instead of olómavri emfánisi 'total black look'

In the examples above, we notice the use of the Anglicisms flat, pencil, trend and total black in the place of the equivalent MG words or phrases. The use of Anglicisms in hybrid structures probably indicates that the speaker/editor has a high degree of knowledge of the latest British and American fashion trends. Moreover, they want to add prestige to their statements, since the borrowed items come from a language system that is considered of high prestige (McMahon, 1994, p. 202).

In particular, in examples (61), (62) and (64) above we may notice that the Anglicism is in a pre-nominal position forming the pattern [uninflected foreign loanword + head noun], which imitates the structure of the English NP (Petrounias, 2007, p. 351, Xydopoulos, 2003, p. 11, Xydopoulos, 2005, 2008). In these particular examples, the pre-nominal modifier, is an uninflected English loanword, that gives hybrid structures of the type [NP NPUNINFLECTED N] (see also Papadopoulou, 2016, pp. 45-46, Papadopoulou \& Xydopoulos, 2016). 


\subsection{Fashion Anglicisms in Greek online shops}

Exploring the websites of the Greek online shops of multinational companies we found out that they tend to use chiefly Anglicisms in order to promote and publicise their products instead of using the native MG term. In Table 2, in the women's section of the online shops of Zara, Bershka and Pull and Bear we find transliterated terms as shown in column (A) along with non-transliterated forms shown in column (B). Not only in women's sections, but in men's sections too, we can find Anglicisms in their transliterated form in (C) and non-transliterated form in (D). In both sections, there are collections that bear the name of English non-transliterated terms (see examples in $\mathrm{E}$.).

\begin{tabular}{|c|c|c|c|c|}
\hline $\begin{array}{l}\text { A. } \\
\text { Transliterated } \\
\text { terms in } \\
\text { women's } \\
\text { sections }\end{array}$ & $\begin{array}{l}\text { B. Non- } \\
\text { transliterated } \\
\text { terms in } \\
\text { women's } \\
\text { sections }\end{array}$ & $\begin{array}{l}\text { C. Transliterated } \\
\text { terms in men's } \\
\text { sections }\end{array}$ & $\begin{array}{l}\text { D. Non- } \\
\text { transliterated } \\
\text { terms in men's } \\
\text { sections }\end{array}$ & $\begin{array}{l}\text { E. Non- } \\
\text { transliterated } \\
\text { proposed } \\
\text { styles in both } \\
\text { sections }\end{array}$ \\
\hline $\begin{array}{l}<\mu \pi \lambda \dot{c}^{<} \iota \zeta \varepsilon \rho> \\
\text { 'blazer' }\end{array}$ & bikers & 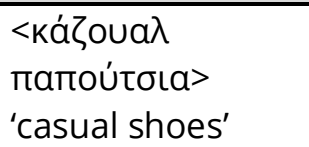 & bomber & back to school \\
\hline 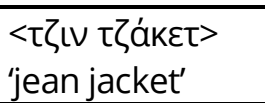 & $\begin{array}{l}\text { body or } \\
\text { bodies }\end{array}$ & $\begin{array}{l}<\mu \pi \lambda \varepsilon^{\prime} \iota \zeta \varepsilon \rho> \\
\text { 'blazer' }\end{array}$ & jogging & denim collection \\
\hline 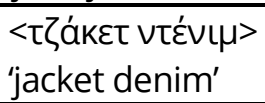 & jeggings & <паркá> 'parka' & shorts & gymwear \\
\hline $\begin{array}{l}<\text { стоп> 'top' or } \\
<\text { сопৎ> 'tops' }\end{array}$ & leggings & 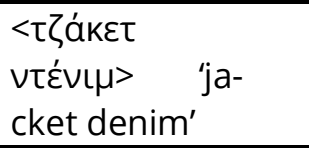 & swimwear & most wanted \\
\hline$<\sigma o p \tau \zeta>$ 'shorts' & sock boots & $\langle\tau \zeta \iota \nu>$ 'jeans' & underwear & party looks \\
\hline
\end{tabular}

Table 2. Fashion Anglicisms in Greek online shops.

As we can see in Table 2, Anglicisms found in MG online shops of the companies under consideration can be either transliterated using the MG alphabet (examples in $A$ and $C$ ) or non-transliterated (examples in $B, D$ and $E$ ), maintaining the form they have in English. The use of the English word in the online shops probably aims to attract prospective customers, since a product that bears a foreign name might be considered more modern, fashionable or of better quality than a product with a Greek label. For example, the terms blazer or bomber might sound more fashionable and stylish than the MG term sakáki 'blazer'.

Considering the fourth online shop, Dangerous Minds, which is a Greek shop based in Thrace, Greece, we surprisingly found that almost all the names of the products in 
the website were in English, although the main language of the site is MG. There are not only non-transliterated loanwords such as sneakers, leggings, jacket, jeans, shorts etc., but also English words such as shirt, dress, and skirt ignoring the equivalent MG words pukámiso 'shirt', fórema 'dress' and fústa 'skirt' respectively, which are commonly used in MG. Probably Greek online shops like the one under consideration, aim to mimic foreign, British or American, online shops in order to attract customers' interest. Customers might have in mind that since the named products are in English, the products are foreign too, and as a result they are more stylish, fashionable and of good quality.

In addition, three of the online shops under consideration constitute a significant example of globalized corporations, since they operate identical stores and online shops in several countries internationally. Consequently, the use of Anglicisms familiarises Greek customers with international fashion terms, as most of them are of English origin due to British and US dominance in the fashion market worldwide. As a result, Greek customers become familiar with these terms and might prefer to buy from foreign online stores.

\subsection{Fashion Anglicisms in Greek social media fashion accounts and blogs}

Interestingly, in social media fashion pages and blogs, the Anglicism is given in its original English form, without being transliterated into the alphabetical system of the recipient language. In the following examples, we notice the insertion of Anglicisms in the Greek text, spelled in English:

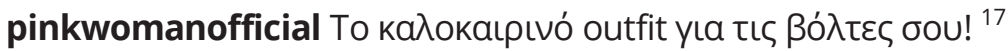
(Lit.: The summer outfit for the walks your) 'Summer outfit for your walks'

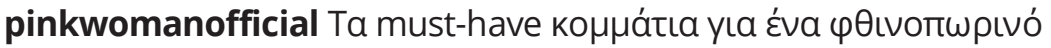
look! ${ }^{18}$

(Lit.: The must-have pieces for an autumn look) 'Must-have pieces for an autumn look'

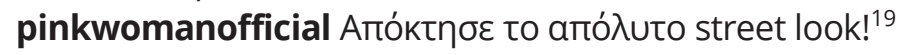
(Lit.: Get the ultimate street look) 'Get the ultimate street look'

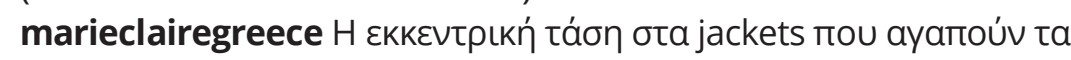

17 https://www.instagram.com/p/BYNZcKYF35K/?taken-by=pinkwomanofficial

18 https://www.instagram.com/p/BZdRC28FJUS/?taken-by=pinkwomanofficial 
fashion girls ${ }^{20}$

(Lit.: The eccentric trend in jackets that love the fashion girls)

'The eccentric trend in jackets that fashion girls love'

The Anglicisms outfit in (65), must-have in (66), look in (66), street look in (67), jackets in (68) and fashion girls in (68) could be transliterated into MG using the symbols of the

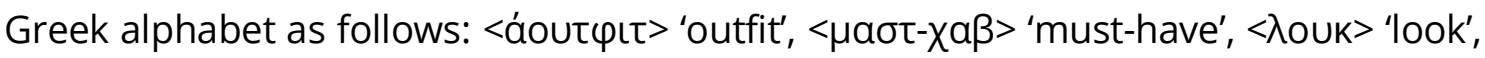

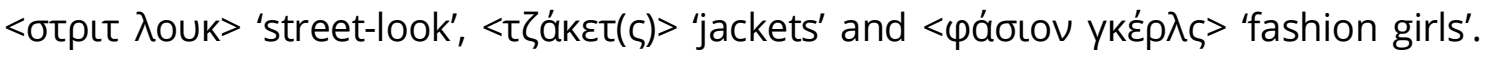
The editor of each of the posts uses the original English orthographic forms of the loanwords to show that the content of their text, or the products they are trying to promote are widely influenced by the English or the American fashion culture. They follow the latest international fashion trends and it is very likely that this would have a positive impact on the image of the reader/receiver/customer.

In particular, example (66) proposes 'must-have' items in order to create a modern autumn look and be admired and desired. The non-transliterated 'must-have' indicates that the proposed items keep up with the international fashion orders and has nothing to do with the probably outdated or old-fashioned Greek way of dressing. As a result, buyers of these items would rather be modern and welldressed. In addition, example (68) proposes some types of jackets that are preferred by fashion girls. The non-transliterated 'fashion girls' shows that the items or styles proposed in the article are preferred by the 'experts' in the domain of fashion, which are influenced by the latest fashion trends coming mainly from the British and American fashion industry. In addition, 'fashion girls' in its original English form, distinguishes between bloggers of international fame from national Greek bloggers, who may not be as well-informed about the domain of fashion or the latest trends. Also, the names of the jackets that are shown in the article are non-transliterated (example 68), which may suggest that they are more modern or of a higher quality. However, the editor tries to persuade the reader to read the article, to attract their interest and finally persuade them to follow the proposed trends in order to be stylish and admired.

\section{Discussion and concluding remarks}

English nowadays is undoubtedly the dominant language of the fashion world. Consequently, it is a considerable source of new, English-originated fashion terms,

http://www.marieclaire.gr/fashion/street-style/ekkentriki-tasi-sta-jacket-pou-agapoun-tafashion-girls/ 
now being used in MG. They enter the MG vocabulary mainly through the Internet, including online stores, blogs, and social media.

Fashion Anglicisms can either be loanwords, loan translations or they can form hybrid structures imitating the equivalent English ones, and belong to categories of clothes, footwear, accessories etc. They are inserted into MG not only due to necessity reasons, i.e. in order to fill a lexical gap or to name a brand-new item or concept, previously non-existent in the Greek fashion industry (e.g. crop top, fashion icon), but for social reasons too. The status of English today is considered remarkably high in prestige and as a result MG speakers tend to borrow the English terms that, in fact, coexist with the equivalent terms in MG (e.g. jumpsuit).

Anglicisms are not immediately adapted to the MG system due to their quick insertion into Greek society and language. What is striking though, is that in many cases online stores as well as social media accounts of stores and magazines use Anglicisms in their non-transliterated form, e.g. outfit, instead of using the MG term, or even a transliterated form.

However, we cannot give an explanation as to why some terms are being transliterated and some are not. We may hypothesise that Anglicisms that have entered the MG vocabulary some years ago, are adapted to the MG system and

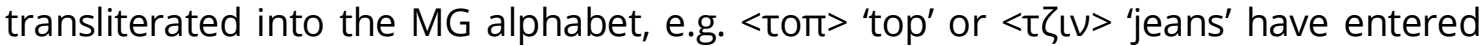
MG a long time ago. On the other hand, Anglicisms that have entered MG in the last couple of decades or later are not yet integrated and, as a result, they are given in their original English orthographic form, e.g. leggings, which appears to be more familiar to users/MG speakers. In some cases, though, it is not immediately clear what the borrowed term is made of, e.g. jeggings < jeans + leggings. ${ }^{21}$ This is a case of an English blend that presumably cannot be calqued into MG (see e.g. Ralli \& Xydopoulos, 2012), and so the Anglicism is adopted in its original English form.

It may be argued that the transliteration of an Anglicism into MG using the MG alphabet might reduce the recognisability of the word. The term is widely known and recognisable or even familiar to MG speakers in its original English form. If, for example, someone tries to transliterate the Anglicism outfit into the MG alphabetical system, and maintaining of course the MG phonological rules, the given result will be

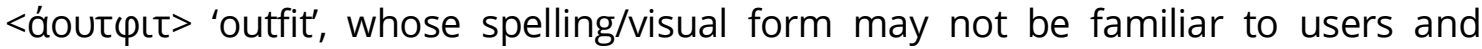
would not allow them to recognise it straightforwardly. Therefore, the spread of the

21 This might be considered a false Anglicism; see Furiassi (2010) and Lopriore \& Furiassi (2015), among others. 
English term is wider and faster in its original English form than in a transliterated or even translated form. It is worth noticing that the majority of Greeks are familiar with the Roman alphabet. Apart from the knowledge of English they have contact with the Latin alphabet in many aspects of everyday life, e.g. in road signs Greek and Latin transliterations coexist. Hence, the existence of hybrid structures in MG where one element is a non-transliterated Anglicism and the other a form written in MG is acceptable.

The claim about the correlation between the transliterated and non-transliterated forms and the level of adaptation of the Anglicisms can be further investigated so as to reach safer conclusions. The use of a customised web-based corpus of MG texts, currently in preparation, will decisively contribute to a further analysis of fashion Anglicisms in MG, since we will be able to give significant information (e.g. determining the date of the first appearance of the Anglicism) and reach safer conclusions regarding the phenomenon under consideration.

\section{Article history}

Paper received: 24 October 2017

Paper received in revised form and accepted for publication: 1 December 2017

\section{About the authors}

Dr. George J. Xydopoulos is Associate Professor of Linguistics at the Department of Philology of the University of Patras. He studied French and Greek (BA Hons) at the University of Athens and specialized in Linguistics at the School of Oriental and African Studies (MA; SOAS) and at University College London (PhD; UCL) of the University of London. For the last twenty-five years, he has taught various undergraduate and postgraduate courses in General Linguistics at SOAS and UCL in London, the University of Hertfordshire, the University of Patras, the University of Ioannina and the Hellenic Open University. His current research and teaching interests fall within the areas of lexicology (lexical morphosemantics, special and subcultural vocabularies), lexical semantics, lexicography and educational linguistics.

Rania Papadopoulou is a second-year Ph.D. candidate in Linguistics. She is 
enrolled in a joint Ph.D. program between University of Patras and the University of Lyon 2 concerning research in the areas of Lexicology, Multilingual Terminology and Translation. She holds a BA Hons. degree in Linguistics and Greek Literature and an MA degree in Linguistics from the University of Patras. Her MA thesis was about the process of Anglicisation in Modern Greek. She is a member of the CRTT laboratory (Centre de Recherche en Terminologie et Traduction) at University of Lyon 2. Her research interests fall within lexicology, language contact and translation.

\section{Acknowledgements}

We would like to thank the editors of the volume for inviting us to submit a paper regarding fashion Anglicisms in Modern Greek. We are also grateful to two anonymous reviewers for their constructive comments and criticism. The usual disclaimer applies. Part of this research has been funded by the General Secretariat for Research and Technology (GSRT) and the Hellenic Foundation for Research and Innovation (HFRI).

\section{References}

Anastasiadi-Simeonidi, A. (1994). Neologikos daneismos tis neoellinikis. Amesa daneia apo tin Galliki kai tin Agloamerikaniki, morfofonologiki analisi. Thessaloniki: Aristotle University.

Balteiro, I. \& Campos, M. Á. (2012). False anglicisms in the Spanish language of fashion and beauty. Ibérica 24, 233-260.

Bybee, J. (2015). Language change. Cambridge: Cambridge University Press.

Fischer, R. (2008). Introduction: Studying Anglicisms. In R. Fischer \& H. Pulaczewska (Eds.), Anglicisms in Europe: Linguistic diversity in a global context (pp.1-17). Newcastle Upon Tyne: Cambridge Scholars Publishing.

Crystal, D. (2003). English as a global language. 2nd ed. Cambridge: Cambridge University Press.

Furiassi, C. (2010). False Anglicisms in Italian. Monza: Polimetrica International Scientific Publisher.

Hjarvard, S. (2004). The globalization of language: How the media contribute to the 
spread of English and the emergence of medialects. Nordicom Review 1-2, 75-97.

Lopriore, L. \& Furiassi C. (2015). The influence of English and French on the Italian language of fashion: Focus on false Anglicisms and false Gallicisms. In C. Furiassi \& H. Gottlieb (Eds), Pseudo-English: Studies on False Anglicisms in Europe [Language Contact and Bilingualism 9] (pp. 197-226). Boston \& Berlin: De Gruyter Mouton.

McMahon, A. (1994). Understanding language change. Cambridge: Cambridge University Press.

Papadopoulou, R. (2016). The Phenomenon of Anglicisms: From Idiomatic MWEs to Morphosyntactic Structures. Unpublished Master Thesis. University of Patras, Department of Philology, Division of Linguistics.

Papadopoulou, R. \& Xydopoulos, G. J. (2016). The influence of English on Modern Greek: Exploring some newly calqued lexical patterns. Paper presented to the ESSE 13 Conference. Galway, 22-26 August 2016.

Petrounias, E. (2007). Neokatharevousa kai eksaglismos tis ellinikis: grammatiko sistima. Studies in Greek Linguistics 27, Proceedings of the annual meeting of the Department of Linguistics Faculty of Philosophy Aristotle University of Thessaloniki 6-7 May 2007 (pp. 348-360). Thessaloniki: IN $\Sigma$.

Pulcini, V., Furiassi, C. \& Rodriguez Gonzalez, F. (2012). The lexical influence of English on European languages: From words to phraseology. In V. Pulcini, C. Furiassi \& F. Rodriguez Gonzalez (Eds), The Anglicization of European Lexis (pp. 1-24). Amsterdam: John Benjamins Publishing Company.

Ralli, A. \& Xydopoulos, G.J. (2012). Blend Formation in Modern Greek. In V. Renner, F. Maniez \& P. Arnaud (Eds.), Cross-disciplinary perspectives on lexical blending (pp. 3550). Berlin: Mouton de Gruyter.

Xydopoulos, G.J. (2003). H dimiourgia ton "Brand Names" sti diafimisi apo mia lexikologiki skopia. ELETO 4o Sunedrio Ellhniki Glossa kai Orologia (pp. 1-12). Athens 30 October - 1 November 2003.

Xydopoulos, G.J. (2005). Mia anazitisi ton glossikon mixanismon dimiourgias ton proiontikon onomaton. Studies in Greek Linguistics 25, Proceedings of the annual meeting of the department of Linguistics Faculty of Philosophy Aristotle University of Thessaloniki 7-9 May 2004. Thessaloniki: IN $\Sigma$.

Xydopoulos, G.J. (2008). Lexikologia: Eisagogi stin analisi tis lexis kai tou lexikou. Athens: Ekdoseis Pataki.

\section{Online sources}

Cambridge Dictionary available at https://dictionary.cambridge.org 
Dictionary.com available at http://www.dictionary.com

English Oxford Living Dictionaries available at https://en.oxforddictionaries.com

Urban Dictionary available at https://www.urbandictionary.com

Wikipedia available at https://www.wikipedia.org

\section{Appendix: Fashion Anglicisms in Modern Greek}

\begin{tabular}{lll}
\hline & List of fashion Anglicisms in MG \\
\hline animal print & jumper & sweater \\
\hline ankle boot & jumpsuit & swimwear \\
\hline baby doll & kimono & suede \\
\hline backpack & knit look & top \\
\hline beach look & leather & total black look \\
\hline bikers & leggings & trend \\
\hline boho style & limited edition & trendy \\
\hline boho chic style & look & t-shirt \\
\hline boyfriend style & maxi & underwear \\
\hline bikini & midi & urban style \\
\hline blazer & mini & vintage \\
\hline body & momfit style & 50s, 60s,70s etc. look \\
\hline bodycon & must-have & gramí álfa 'a-line' \\
\hline bootcut & navy look & metalikés leptoméries \\
& & 'metallic details' \\
\hline bralet or bralette & nylon & psilómesos 'highwast(ed)' \\
\hline brand & old-fashioned & sakídio plátis 'backpack' \\
\hline cashmere & office look & tsáda xirós 'handbag' \\
\hline casual & organza & \\
\hline casual look/style & outfit & \\
\hline catwalk & parka & \\
\hline classic & party look & \\
\hline cutch (bag) & pattern & \\
\hline cocktail dress & peep-toe & \\
\hline crop top & pencil & \\
\hline denim & pullover & push-up \\
\hline denim jacket & rock & \\
\hline design & rock style & \\
\hline dress code & & \\
\hline & & \\
\hline
\end{tabular}




\begin{tabular}{ll}
\hline dress to impress & see-through \\
\hline extreme & sexy \\
\hline extreme look & shorts \\
\hline fashion icon & slim style \\
\hline fashionista & slimfit style \\
\hline flat & skinny \\
\hline floral & sneakers \\
\hline girly look & smoking \\
\hline glam style & sock boots \\
\hline glitter & sport \\
\hline handbag & spring, summer, autumn, \\
\hline handmade & winter look etc. \\
\hline hippie style & strapless \\
\hline jacket & street style \\
\hline jeans & style \\
\hline jeggings & stylish \\
\hline jersey & sweater \\
\hline jogging & swimwear \\
\hline
\end{tabular}

